\title{
POLITICAL RESPONSES TO CHILD LABOUR IN INDIA - ANALYZING NATIONAL AND INTERNATIONAL SYMBOLISM
}

\author{
Aryan Mahajan \\ The Doon School, Uttarakhand \\ DOI: 10.46609/IJSSER.2020.v05i06.019 URL: https://doi.org/10.46609/IJSSER.2020.v05i06.019
}

\begin{abstract}
The incidence of child labour is a social issue that continues to plague India's children and social fabric. This leads to a continued cycle of poverty, lack of access to education and exploitation. While there have been several schemes implemented to tackle the same, all are a result of representation and symbolism that is from an abolitionist perspective rather than one that is rehabilitative, and focused on social inclusion, education, and the perception of the rights that working children have for themselves. This representation and symbolism on both the national and international level is problematic, as it has not led to much structural reform in terms of tackling the systemic and structural inequalities that have resulted in child labour occurring. Further, there is no real reform with respect to penalizing corporations either. This paper will critique abolitionist symbolism from a sociological and political perspective, and argue that in the developing context, rehabilitative and consultative policy is the way forward to address the issue of child labour, rather than statistics or campaigns that seek to save children only by banning child labour.
\end{abstract}

Keywords: Child Labour, Social Issue, Child Rights, Education

\section{INTRODUCTION}

The incidence and usage of child labour continues to be a pervasive issue in India, despite governmental regulations and continued activism against the same. Child labour impedes children from gaining the skills and education they need to have opportunities of decent work as an adult. Inequality, lack of educational opportunities, slow demographic transition, traditions and cultural expectations all contribute to the persistence of child labour in India (UNICEF, n.d). There has been a substantial amount of research related to child labour, and it has been interdisciplinary in nature, across economic, political, and social lines. 


\section{International Journal of Social Science and Economic Research}

ISSN: $2455-8834$

Volume: 05, Issue: 06 "June 2020"

This has resulted in activism and legislation, for example Child Labour (Prohibition and Regulation) Act of 1986 which prevents the employment of children below the age of 14 years in life-threatening occupations identified in a list by the law and the subsequent passage of the Juvenile Justice (Care and Protection) of children Act of 2000 made the employment of children a punishable offence (Oxfam, 2018). The National Policy on Child Labour seeks to adopt a sequential approach with focus on rehabilitation of children working in hazardous occupations \& processes in the first instance; and the Ministry of Labour and employment functions to provide and supervise a range of policies concerning child labor in India (Oxfam, 2018). Furthermore, NGOs such as Care India, Child Rights and You, Global March against Child Labour have been implemented to combat child labour through education and accessibility to resources (Osment, 2017). However, these efforts have been largely unsuccessful.

Governments and politicians have largely represented the issue as one which requires children to be saved, appealing to corporates and other stakeholders to play their part in reducing the incidence of child labour. However, despite such campaigns by successive governments, there seems to be no systemic or structural change in terms of imposing large enough penalties or regulating corporations in India. Companies including Gap, Primark and Monsanto have been criticised for child labour in their products (Bahree, 2008). The companies claim they have strict policies against selling products made by underage children, but there are many links in a supply chain making it difficult to oversee them all (Bahree, 2008).

This paper will therefore analyze the manner in which child labour is represented in policy and popular discourse, critiquing the common approaches used by the Indian government as well as international governments and organizations. The paper will critique the merely symbolic manner in which child labour seems to be addressed, and finally pose policy recommendations for more systemic and meaningful reform.

\section{BACKGROUND}

An encouraging statistic is that the incidence of child labour has decreased in India by 2.6 million between 2001 and 2011 (ILO, 2017). However, the decline was more visible in rural areas, while the number of child workers has increased in urban areas, indicating the growing demand for child workers in menial jobs (ILO, 2017). Child labour has different ramifications in both rural and urban India (ILO, 2017). There are five states which are India's biggest child labour employers - Bihar, Uttar Pradesh, Rajasthan, Madhya Pradesh and Maharashtra (Save the Children, 2016). Over half of India's total child labour population works here. India's biggest hub of child labour is Uttar Pradesh and it accounts for almost $20 \%$ of India's child labourers (Save the Children, 2016). 


\section{International Journal of Social Science and Economic Research}

ISSN: $2455-8834$

Volume: 05, Issue: 06 "June 2020"

Despite rates of child labour declining over the last few years, children are still being used in some severe forms of child labour such as bonded labour, child soldiers, and trafficking (UNICEF, n.d). Across India child labourers can be found in a variety of industries: in brick kilns, carpet weaving, garment making, domestic service, food and refreshment services (such as tea stalls), agriculture, fisheries and mining (UNICEF, n.d). Children are also at risk of various other forms of exploitation including sexual exploitation and production of child pornography, including online (UNICEF, n.d). Child labour and exploitation are the result of many factors, including poverty, social norms condoning them, lack of decent work opportunities for adults and adolescents, migration and emergencies (UNICEF, n.d). These factors are not only the cause but also a consequence of social inequities reinforced by discrimination.

Symbolism and representation are valuable to the way in which a policy and social problem is framed. However, from a sociological standpoint, it will not serve to change the demographics of child labour without being followed by effective reform. Corporates who are major employers of child labour cannot undertake campaigns denouncing the same (Nagaraj, 2017). The private sector, civil society and government must work together on interventions for child labour-free zones (Nagaraj, 2017). Other than punitive action, there has been not much progress with respect to education and addressing dropout rates.

National aggregates in this respect tend to be misleading due to the large number of regional variations (Sampath, 2016). For example, while Karnataka has a dropout rate of 2.3 per cent, which is below the national average, Rajasthan's, at 8.39 per cent, is double the national rate, and Manipur's is four times, at 18 per cent. The variations are sharper if the data is disaggregated to district level (Sampath, 2016). For example, if we take Andhra Pradesh, as per Educational Statistics 2013-14 data, the state as a whole had a secondary school dropout rate of 26.83 per cent. But the Maoist insurgency-affected district of Kurnool had an extremely high dropout rate of 45.02 per cent (Sampath, 2016).

Therefore, governmental policy and symbolic representation relating to child labour most often is statistical and displays progress by calculating a national average. However, this does not account for the various structural and nuanced issues that must be accounted for at the regional level, which is especially important in the Indian context given that regional cultures are so divergent (Sampath, 2016). Such sharp variations between states and even within states suggest that local, social and cultural factors play a major role in school retention and, therefore, any intervention to reduce dropouts and consequently child labour, need to be rooted in local contexts (Sampath, 2016). The following section will further critique such statistical reportage and further nuances in the discourse. 
International Journal of Social Science and Economic Research

ISSN: $2455-8834$

Volume: 05, Issue: 06 "June 2020"

\section{DISCUSSION}

International organizations and governments also perceive child labour in India to be a pervasive, problematic issue that is robbing children of their education and childhoods. UNICEF, the ILO and Oxfam are among several such organizations which have extensively catalogued the issue in India. Kailash Satyarti, an activist fighting against child labour, was also awarded the Nobel Peace Prize. International attention does shape policy responses, showing the value that attention and symbolism can bring. For example, the Juvenile Justice Act came into force shortly after India ratified the Convention on the Rights of the Child (CRC), in 1992 and made the offence punishable with imprisonment from three months to one year or with fine no less than INR 10,000-20,000 rupees or with both (Oxfam, 2018).

However, several child rights organizations have noted that representation and simply banning child labour as a result of symbolic representation is not enough, and cannot replace robust policy (Amnesty International, 2014). For example, most recently, Kailash Satyarti proposed an amnesty to be declared for all child labour prosecutions for the three months, due to the COVID19 pandemic (Ganguly and Menon, 2020). This is because, according to him, reaching out to trafficked children stuck in factories across states is difficult on account of the stringent lockdown conditions. He believes this makes it next to impossible to reach them and rescue them (Ganguly and Menon, 2020). However, this was criticized by activists as once again favouring employers rather than the children, who instead proposed stronger implementation of the Child and Adolescent Labour (Prohibition and Regulation) Act, 1986 as well as the Juvenile Justice Act, 2015, as well as exemptions from lockdown measures for child protection services, more support for child labour related civil society organizations, government sponsored transportation of child labour, among others (Ganguly and Menon, 2020).

Statistical reportage remains inadequate and inaccurate for a global image of a rapidly developing country, because it does not shed a light on industry specific conditions and reduces the issue to percentages that when viewed on a macro level, could seem advantageous. For example, a common statistic as mentioned in this paper is the decline of child labour from 2001 to 2011 may seem encouraging. However, a 2017 UNICEF report, based on Indian census data, says the proportion of child workers in the 5- to 9-year age group jumped to 25 percent in 2011 from 15 percent in 2001 (Nagaraj, 2017). Many companies do not engage children in their own facilities but have no checks when they subcontract production to smaller factories or home workers, where the prevalence of child labour increases drastically (Nagaraj, 2017). Child labour has often moved further down the supply chain, making monitoring more difficult (Nagaraj, 2017). 


\section{International Journal of Social Science and Economic Research}

ISSN: $2455-8834$

Volume: 05, Issue: 06 "June 2020"

Additionally, child labour remains gendered, which is not adequately accounted for in statistical reportage. The UNICEF noted that girls are often deployed in household domestic labour while boys are sent out to the fields and into the mines (Oxfam, 2018). A study by Oxfam further corroborated these findings, in their study of the sugarcane farmers of Uttar Pradesh, where it was found that labour contractors were selling children as labour to small scale farmers, because they were cheaper to feed and did not need to be paid (Oxfam, 2018). Therefore, there is a need

for more extensive studies and research implemented in particular regions to identify the root causes of child labour and work towards a more rehabilitative approach.

\section{CONCLUSION}

What is clear from the above analysis is that while symbolism and campaigns from government and civil society are valuable, there is a dire need for a stronger resolve to address violations of rights, activating and strengthening the civil society partnerships that enable the detection, prosecution, rescue and rehabilitation of the child labourers (Ganguly and Menon, 2020). There must also be a willingness from all of society to embrace more novel ideas such as working childrens' organisations, which could have large value in terms of much more grassroots and systemic reform which is the need of the hour in developing contexts (CWC, n.d). There is a need for a departure from an abolitionist perspective to a rehabilitative perspective, which working childrens' groups can offer (Daalon and Hanson, 2016; CWC, n.d).

Working children's organisations have had limited success in challenging dominant abolitionist perspectives on child labour. Working children's realities and conceptions of rights need to be taken more seriously in international debates (Daalen and Hanson, 2016). An example of their effectiveness in India is the Bhima Sangha, a union of working children, who were instrumental in setting up the first local children's councils in the state of Karnataka (CWC, n.d). Working children's organisations take a dissenting position in the child labour debate, fighting an uphill battle against the dominant, abolitionist approach endorsed by the International Labour Organisation (ILO), many large development organisations, and international NGOs (Daalen and Hanson, 2016). The mainstream abolitionist approach is backed by international legislation on child labour, which aim to prohibit child labour under certain minimum ages and immediately abolish the 'worst forms' of child labour (Daalen and Hanson, 2016).

A study on the priorities of international children's rights advocacy, found that the discourse produced by UN entities and international NGOs pay scant attention to the positions defended by working children's organisations. Instead, they most often speak of children as innocent victims in need of being 'saved' from harm (Daalen and Hanson, 2016). As such, the major themes of the international agenda are the specific needs and rights of children exposed to emergencies; 


\section{International Journal of Social Science and Economic Research}

ISSN: $2455-8834$

Volume: 05, Issue: 06 "June 2020"

children's basic needs; the worst forms of child labour; and violence against children (Daalen and Hanson, 2016).

Notwithstanding discourses by leading child rights organisations about children as active participants and rights holders, are most often essentialised as vulnerable and innocent human beings who cannot know what is best for themselves (Daalen and Hanson, 2016). 'Stop child labour' campaigns thus do not address the local perspectives of working children, that of their families, or that of working children's organisations (Daalen and Hanson, 2016). Instead, the ideologies behind the campaigns seem to be immune to the nuanced positions of concerned working children who, in fact, exercise agency by asking for a more realistic approach to the regulation of their working conditions. In doing so, they ignore the human agency that lies at the very core of the human rights framework (Daalen and Hanson, 2016).

Child labour must not be represented as requiring compassionate saviour from the outside. Rather, working children must have their own rights conceptions be taken seriously (Daalen and Hanson, 2016). To do so would require all levels of governance, including international frameworks, to begin addressing the structural inequalities at the heart of working children's exploitation (Daalen and Hanson, 2016).

\section{REFERENCES}

Amnesty International India, (16 December 2014), 'Robust Means Needed To Act Against Child Labour: Amnesty International', https://amnesty.org.in/robust-means-needed-act-childlabour-amnesty-international/

Bahree, M, (3 October 2008), "Child Labor", Forbes, https://www.forbes.com/global/2008/0310/062.html\#fce10e74cc63

Concerned for Working Children (CWC), (n.d), 'Children's Unions', http://www.concernedforworkingchildren.org/empowering-children/childrens-unions/

Daalen E and Hanson K, (26 February 2016), 'Can Campaigns to stop child labour be stopped?', Open Democracy, https://www.opendemocracy.net/en/beyond-trafficking-andslavery/can-campaigns-to-stop-child-labour-be-stopped/

Ganguly, E and Menon, M, (29 April 2020), 'Kailash Satyarthi Should Know There's No Place for Dilemmas When it Comes to Child Labour', The Wire, https://thewire.in/rights/kailash-satyarthi-should-know-theres-no-place-for-dilemmaswhen-it-comes-to-child-labour 
International Journal of Social Science and Economic Research

ISSN: 2455-8834

Volume: 05, Issue: 06 "June 2020"

International Labour Organization (ILO), (8 June 2017), 'Fact Sheet: Child Labour in India', https://www.ilo.org/newdelhi/whatwedo/publications/WCMS 557089/lang-en/index.htm

Nagaraj, A, (2 May 2017), 'Send children 'to work' at school to end child labour - activists', Reuters, https://www.reuters.com/article/india-children-labour-idUSL4N1I04JY

Osment, E, (2017). "Child Labour; The Effect on Child, Causes and Remedies to the Revolving Menace". Lund University Publications: 9-14.

Oxfam, (20 November 2018), 'Child Labour \& Child Rights in India: Myth or Reality', https://www.oxfamindia.org/blog/child-labour-india

Sampath, G, (11 December 2016), 'Why Children Drop out From Primary Schools', The Hindu, https://www.thehindu.com/news/national/Why-children-drop-out-from-primaryschool/article16792949.ece

Save the Children, (4 May 2016), 'Statistics of Child Labour in India State Wise', https://www.savethechildren.in/articles/statistics-of-child-labour-in-india-statewise\#: : text=It\%20is\%20not\%20surprising\%20that,Report\%20on\%20Child\%20Labour \%202015).\&text=According\%20to\%20Census\%20data\%2C\%20there, $\%$ E2\%80\%93\%20 14\%20years)\%20in\%20India.

UNICEF, (n.d), 'Child Labour and Exploitation', https://www.unicef.org/india/what-wedo/child-labour-exploitation 